The research program of the Center for Economic Studies (CES) produces a wide range of theoretical and empirical economic analyses that serve to improve the statistical programs of the U.S. Bureau of the Census. Many of these analyses take the form of CES research papers. The papers are intended to make the results of CES research available to economists and other interested parties in order to encourage discussion and obtain suggestions for revision before publication. The papers are unofficial and have not undergone the review accorded official Census Bureau publications. The opinions and conclusions expressed in the papers are those of the authors and do not necessarily represent those of the U.S. Bureau of the Census. Republication in whole or part must be cleared with the authors.

\title{
THE IMPACT OF OWNERSHIP CHANGES: A VIEW FROM LABOR MARKETS
}

by

\author{
Robert H. McGuckin \\ The Conference Board
}

and

\author{
Sang V. Nguyen \\ U.S. Bureau of the Census \\ Center for Economic Studies
}

CES 00-02 March, 2000

\begin{abstract}
All papers are screened to ensure that they do not disclose confidential information. Persons who wish to obtain a copy of the paper, submit comments about the paper, or obtain general information about the series should contact Sang V. Nguyen, Editor, Discussion Papers, Center for Economic studies, Washington Plaza II, Room 206, Bureau of the Census, Washington, DC 20233-6300, (301-457-1882) or INTERNET address snguyendces.census.gov.
\end{abstract}




\title{
The Impact of Ownership Changes: A View from Labor Markets \\ by \\ Robert H. McGuckin and Sang V. Nguyen ${ }^{1}$
}

February, 2000

\begin{abstract}
Previous studies of mergers and acquisition often focus on firms' performance such as profits, productivity and market shares. However, from a broad competition policy perspective, the impacts on labor and wages are crucial. In this study, we use plant-level data for the entire U.S. manufacturing for the period 1977-87 to examine the effects of ownership changes on employment, wages and plant closing. Our principal findings are that ownership changes are not a primary vehicle for cuts in employment and wages, or closing plants. Instead, the typical ownership change appear to increase jobs and their quality as measured by wages. However, some ownership changes, particularly those in bigger plants, are associated with job loss, and the typical worker fares much worse than the typical plant. Finally, we find that plants that changed owners have a higher probability of survival than those that did not. Overall, the impact of ownership changes on labor markets are positive.
\end{abstract}

Keywords: Ownership Change; employment; wages; plant closing;

JEL Classification: D21, G34, J65, L6

1 The authors are Director of Economic Research, Conference Board Inc. and Economist, Center for Economic Studies (CES), U.S. Bureau of the Census. The views expressed herein are those of the authors and do not necessarily reflect those of The Conference Board or the U.S. Bureau of the Census. The authors would like to thank David Audretsch and an anonymous referee for their thoughtful comments, and Rebecca Turner for her skillful typing. The authors are responsible for any remaining errors. 


\section{INTRODUCTION}

Competition policy encompasses a wide range of issues -- production efficiency, property rights maintenance, labor policies, and contract rules -- many of which go well beyond traditional antitrust concerns. Antitrust analysis typically emphasizes static deviations of price from marginal cost. (See Caves, 1989, Ecko, 1983 and 1985, and Grundfest, et. Al., 1988). For example, the decision to block a merger usually turns on the issue: Will the merged firm be able to increase price? Answering this question involves an assessment of whether the merger will create a monopoly or increase the possibilities for collusion.

In this limited decision framework the potential gains to particular mergers from efficiencies and reallocations of resources do not play an important role. This is not because merger induced efficiencies are not recognized. Their importance has been well understood since the work of Williamson (1968) and Jensen (1988) emphasized the potential for improved productivity and reduced costs from reallocating resources within the firm. Furthermore, recent work by Lichtenberg and Siegel(1992) and McGuckin and Nguyen (1995) strongly support that mergers generate productivity gains. Moreover, antitrust authorities have specifically recognized the importance of efficiencies in the merger guidelines. ${ }^{2}$

What has been less recognized is that the efficiencies that arise in mergers often come from the displacement of jobs and lower wages. Viewed from this perspective, the policy context moves well beyond static analysis. In this broader context, labor market impacts - particularly in dynamic markets where rapid change requires the reallocation of resources from inefficient to efficient producers - are crucial because changes in the structure of a firm's employment are often an important factor in achieving gains to mergers. For example. Lichtenberg and Siegel (1992) find declines in the number of white-collar workers following mergers. Since many of the potential efficiencies from mergers are associated with workforce adjustments, ownership changes are typically subject to strong opposition from labor unions and widespread, often negative, press reports. ${ }^{3}$ Jobs and wages are frequently more important than deadweight losses and monopoly rents in the formation and support of public policy. Even within the more narrow confines of mergers and acquisitions, where research centers on antitrust and failures in corporate governance, worker impacts play an important role.

2 See revised Section 4, Horizontal Merger Guidelines, issued by the U.S. Department of Justice and the Federal Trade Commission, April 8, 1997 which states:

Competition usually spurs firms to achieve efficiencies internally. Nevertheless, mergers have the potential to generate significant efficiencies by permitting a better utilization of existing assets, enabling the combined firm to achieve lower costs in producing a given quantity and quality than either firm could have achieved without the proposed transaction. Indeed, the primary benefit of mergers to the economy is their potential to generate such efficiencies.

Efficiencies generated through merger can enhance the merged firm's ability and incentive to compete, which may result in low prices, improved quality, enhance service, or new products. For example, merger-generated efficiencies may enhance competition by permitting two ineffective (e.g., high cost) competitors to become one effective (e.g., low cost) competitor... Efficiencies also may result in benefits in the form of new or improved products, and efficiencies may result in benefits even when price is not immediately and directly affected.

In practice, these efficiencies are often not a major factor in individual cases since it is difficult to estimate the extent of potential efficiencies at the time of the merger (Rule and Meyer (1994)), Posner (1976).

3 Organized labor has expressed its concern regarding mergers and acquisitions: Workers and their unions have a vital interest in the corporate takeover issue. Corporate mergers, takeovers, and leveraged buyouts often have serious effects on job, wages, and working conditions (AFL-CIO 1987, E1). 
It is not surprising that labor and local communities would view ownership changes negatively. It is easy to find examples of communities torn apart and particular sets of workers dismissed. Operational changes arising from ownership change can generate management dismissals, plant closings, reductions in pensions and lower wages. ${ }^{4}$ Since particular groups suffer in the process, they can be expected to support rules and restrictions designed to protect their interests. The experience with state takeover legislation in the 1970s and 1980s illustrates the political pressure that can arise in periods of concentrated mergers and acquisitions involving substantial resource reallocations. Most rust belt state governments enacted legislation in an attempt to stop mergers involving companies with large local presence in the 1970 s in the belief that mergers were a primary factor in job destruction (Guerin-Calvert, et. al. (1987)). Thus, though previous studies often focus on the effects of mergers and acquisitions on measures of firm performance such as profits, market share, and prices, to answer policy concerns requires that we look at different measures, particularly labor and wages.

While the reallocations of productive resources that accompany ownership changes are intimately linked to the creative destruction, the dynamic efficiency of firms and market competition (e.g., see Jensen, 1988 and Salop, 1988) systematic evidence on the net effects of mergers on labor reallocation is scarce. The lack of empirical research on this topic is due to the fact that appropriate data were not available. Recently, plant-level data on employment, wages, establishment birth and death, and ownership changes have become available in the Census Bureau's Longitudinal Research Database (LRD). These data provide a unique opportunity for researchers to examine the impact of ownership change on labor market outcome. In this article, we use LRD data to assess the impact of ownership

changes on employment, wages and plant closings for the large merger wave of the 1980s. Our data cover the entire universe of the U.S. manufacturing sector for the period $1977-87 .{ }^{5}$

Our principle findings are that overall mergers and acquisitions are not a primary vehicle for cuts in wages and employment: The typical ownership change transaction increases the number of jobs and their quality as measured by wages. In addition, the evidence suggests that survival probabilities are higher for plants that change owners than for those that do not. On the other hand, some ownership changes, particularly those in bigger plants, are associated with enormous job loss and the typical worker fares much worse than the typical plant. Nonetheless, the overall impact on production jobs is positive.

Our results also suggest that employment and wage growth at the surviving plants of acquiring firms are not greatly affected by the acquisitions. However, the evidence also suggests that both the level and growth rates of wages are higher at the plants of acquiring firms than that at plants owned by nonacquirers.

The remainder of the paper is organized as follows. In the next section, we briefly describe existing studies and our data and sources. Some descriptive statistics are presented next, followed by the empirical model. We then outline our basic empirical findings, discuss the results, and close with a short conclusion.

\section{MEASUREMENT AND DATA SOURCES}

4 For example, afer the merger of $\mathrm{MCl}$ and Worldcom in December, 1998, the following news was found in the St. Louis Post Dispatch on December 17, 1998:

"The ax is falling for 52 workers at MCI Worldcom in St. Louis. The local layoffs are part of MCl's plan to cut 2,000 jobs by the end of the year. The cuts result from the recent merger of $\mathrm{MCl}$ and Worldcom, and most will be in network operation and information technology".

${ }^{5}$ We discuss the data in more detail in the next section. 
While ownership change is often associated with intense restructuring of the firm, the theoretical relationship between ownership change and workers is not obvious. Some ownership changes -- hostile takeovers as one example -- are infamous because of publicity associated with the wholesale changes that accompany them: management dismissed, plants closed, pension benefits abrogated, and wages reduced. But, ownership change need not be associated with downsizing and plant closure. ${ }^{6}$ New ownership can bring new capital, marketing outlets, and expertise to a firm. Such changes are just as likely to be precursors of growth and job creation. ${ }^{7}$

Wages offer similar problems. They may go up or down following an ownership change. The precise outcome depends on many factors such as how the composition of employees shifts, the effect of the transaction on the distribution of rents between labor and ownership, or whether rents increase (market power transaction). ${ }^{8}$ In the face of these differences in potential outcomes, we turn to empirical analysis.

\section{Previous Studies}

There have been few studies of the link between ownership change and wages and employment. Brown and Medoff (1988) examined a sample of mostly small firms in the state of Michigan and found that, except for divestitures, ownership change had little effect on employment and wages. Lichtenberg and Seigel (1992b), using a sample of large manufacturing plants from the Census Bureau's Longitudinal Research Database (LRD), found ownership change associated with reductions in both employment and wages at central offices, but not at establishments engaged in production. Most recently, McGuckin, Nguyen and Reznek (1998) examined plant data for the entire U. S. food manufacturing industry (SIC 20) for the period 1977-87. They found ownership change positively associated with labor productivity and, to a lesser extent, wage and employment growth. They also found that plants undergoing ownership change had a greater likelihood of survival.

While the above studies provide valuable insight, their results are subject to certain limitations.

Brown and Medoff's results are based on a single state, while those of McGuckin, Nguyen and Reznek are based on a single industry. Lichtenberg and Siegel (1992b) is the only study covering manufacturing broadly. But, it ends in 1981, well before the end of the 1980s merger wave, and the sample is restricted to larger plants.

\section{New Data Available}

With the development of the Longitudinal Research Database (LRD) at the Census Bureau, data are now available on the operations of plants both before and after ownership change. An important feature of the LRD is its plant classification and identification information: These include firm affiliation, location, product and industry, and various status codes which identify, among other things, birth, death, and

${ }^{6}$ Even among hostile takeovers the public image of massive layoffs appears to be shaped by a small number of cases. Recent work by Gauchely, Groshen, and Neumark (1994), finds that the effects of hostile takeovers on workers are mostly compositional: Hostile takeovers do not reduce workers shares of the total rents to the firm, but they do reduce payments to senior workers by reducing their employment and flattening wage-seniority profiles.

7 Ownership changes do not necessarily lead to any changes in the operation of the firm: In the case of a public firm, ownership is constantly changing, but most such changes bear little relationship to a firm's dayto-day operations. Yet, ownership changes involving "control" -- the type of transaction examined in this study -- usually lead to operational changes encompassing a wide range of things -- from managerial and work practices to changes in the products produced and the technologies used to produce them. Such changes shift the size and composition of the labor force.

8 Monopoly rents may be shared with labor, especially where strong unions are present. 
ownership changes. ${ }^{9}$ These identifying codes are used in developing both the longitudinal plant

linkages and ownership linkages among every manufacturing plant in operation during the 1977-87 period at three discrete points in time, 1977,1982 , and $1987 .^{10}$

All plants having an ownership change during the period were associated with the firm owning them in 1987. This provides a balanced panel of nearly 140 thousand plants surviving until 1987 of which about 16 thousand plants experienced an ownership change. The panel includes, for comparison purposes, all those plants that remained under the same ownership over the period. Finally, all plants exiting and entering during the period and whether or not they were associated with a firm involved in an ownership change were identified.

This design provides complete coverage of the manufacturing population over a period that includes virtually the entire 1980's merger movement. We report results for the 1977-87 time period, avoiding the influence of the cyclical trough that ended in $1982 .{ }^{11}$

\section{DESCRIPTIVE STATISTICS}

Table I reports information on our data and ownership change over the sample period. Of the 314,885 plants in operation in the manufacturing sector in $1977,20,383$ or 7 percent underwent ownership change between 1977-87. These plants accounted for nearly 4.5 million workers, 24 percent of 1977 employment in manufacturing. Thus, on average, plants undergoing ownership change were bigger: The average size of an acquired plant is over 200 employees compared to about 40 for a continuing plant of a non-acquiring firm.

\section{Balanced Panel}

Turning to the balanced panel, roughly 80 percent of the plants changing ownership were still operating in $1987 .{ }^{12}$ These surviving plants accounted for 3.4 million workers in 1987, about 8 percent fewer

9 For a more complete description of the LRD see McGuckin and Pascoe (1988), and for a discussion of the identification of ownership changes in the LRD see Nguyen (1998).

${ }^{10}$ Each of these years coincides with a complete Census of Manufacturers in which information on ownership and other plant characteristics are available for the entire population of manufacturing plants. Many of these plants were not directly surveyed in the manufacturing censuses. Information for these plants was based on administrative records. In our regression analysis, these plants are excluded because their records do not contain complete information. In non-census years information is available only for a sample of plants. Using the Census year data means that ownership change is observed only for five-year intervals. As part of earlier work, McGuckin and Nguyen (1995), we examined these procedures for a sub-sample of our plants for which we could identify their merger activity yearly and concluded that evaluations of plant ownership at five-year intervals were acceptable.

11 We also examined ownership changes for the sub-period 1977-82. Evaluating performance 5 to 9 years after an ownership change allows the acquiring firm time to integrate acquired plants into the firm, or to dispose of them. We therefore, only report results for the whole period 1977-87.

12 About 14 percent of those operating in $1987(2,146)$ experienced more than one ownership change. The 80 percent survival rate of acquiring firms' plants appears to be much higher than those found by Dunne, Roberts and Samuelson (1988 and 1989), Audretsch (1995), and others. We note, however, that the Dunne-RobertsSamuelson rate, for example, was for new entrants only, while ours is for acquiring firms' plants which are older and much larger than new entrants. Because older and larger plants are less likely to exit than younger and smaller, new entrants (e.g., see Dunne, Roberts and Samuelson, 1988), our results appear to be reasonable and are not inconsistent with previous findings. 
workers than the 3.7 million they employed in 1977. Thus, the average size of plants with an ownership change declined by 10 percent, from 232 to 211 , over the 10-year period. Over the same time interval, plant size increased by 3 percent, from 73 to 75 employees, for plants remaining under the same ownership. Thus, the data are consistent with the hypothesis that, overall, job loss and downsizing are associated with mergers and acquisitions.

The plant closing data are also consistent with a positive relationship between job loss and ownership change. Firms undertaking acquisitions closed 43 percent of the plants they owned in 1977. In addition, acquiring firms closed about 21 percent of the plants they acquired. ${ }^{13}$ In contrast, firms with no acquisitions closed plants at a faster rate, about 57 percent of those operated in 1977. But the average size of a plant closed by an acquiring firm was much bigger, about 165 employees versus 19 for nonacquirers.

Consistent with the almost universal finding that larger plants pay higher wages than smaller plants (e.g., see Mellow, 1982, Oi, 1983, Brown and Medoff, 1989 and 1990), the wages in plants of acquiring firms were generally higher than in those in non-acquiring firms. For example, wages were over $\$ 3,000$ per year higher in plants of acquiring firms than in those owned by firms with no ownership changes $(\$ 22,856$ versus $\$ 19,571)$ in 1987 and, the average wage was less in plants acquired $(\$ 22,856)$ than in plants owned prior to acquisition $(\$ 24,599)$. Acquiring firms also paid higher wages in newly created plants $(\$ 22,317$ versus $\$ 17,000)$.

Not only was the level of wages higher in acquiring firms, the average wages in plants owned by acquiring firms increased over the period while wages for workers in non-acquiring firms fell. Acquired plants showed an increase in wages of just under $\$ 1,000$ over the period, about 5 percent. Workers in surviving plants owned by acquiring firms achieved similar gains, from $\$ 23,117$ to $\$ 24,599$. In contrast, the average wage of workers in continuously operating plants of non-acquiring firms fell from $\$ 20,015$ to $\$ 19,571$. Thus, the picture for mergers and acquisitions appears mixed, fewer jobs, but higher wages.

\section{Size Matters}

Table II confirms the importance of size differences in understanding the effects of ownership changes. Although there are substantial differences in the levels of employment and wages between the plants of acquiring and non-acquiring firms, the differences are substantially reduced once the data are

13 This is an understatement since we didn't follow plants acquired after 1987. If one focuses exclusively on plants undergoing ownership change in the 1977-82 period, the percentage of plants closed by 1987 is about 33 percent. 
classified by size.

Non-acquiring firms' plants are heavily concentrated in the smallest size class (1-50), while those of acquiring firms fall more heavily in the larger size classes. However, the relationships of wages and employment are quite similar across the size classes to their 1977 values are quite similar. Both wages and employment show fairly steady declines in growth as size increases (wage growth in the above 500 class is an exception for acquiring firms

Of course, size is only one of many factors that needs to be controlled for before one can draw conclusions about the effects of ownership change. For this reason, we turn to a regression analysis that allows us to assess the impact of ownership change on employment and wages while controlling for the effects of other factors.

\section{EMPIRICAL MODEL}

\section{Wage and Employment}

We use the same basic wage and employment equations used in McGuckin, Nguyen, and Reznek (1998). These specifications are also similar to those used by Brown and Medoff (1988) and Lichtenberg and Siegel (1992b). They reflect standard practice in the literature analyzing the impact of training on workers' earnings and employment. ${ }^{14}$ The basic idea underlying the equations is to ask whether changes in ownership had significant effects on employment and wages controlling for the initial conditions (i.e., initial employment and wages). The empirical model relates changes in plant employment and wages to ownership change (endogenous) and predetermined explanatory variables. Its general form is:

$$
\begin{aligned}
\ln X_{87}-\ln X_{77}=a o+a_{1} D+a_{2} O+a_{3} \ln W_{77}+a_{4} \ln E_{77} \\
+a_{14} D^{*} \ln E_{77}+a_{24} O \ln E_{77}+a_{5} \ddot{A}(K / L) I+a_{6} \ddot{A} T+a_{7} A ̈(N / P) \\
\left.+a_{8} M+G_{k} A_{g e} e_{k i}+G c_{r} R_{e g i o n}+G_{r i} I N D_{m i}\right)+e_{i}
\end{aligned}
$$

where In is natural logarithm; $\mathrm{X}$ denotes total employment (number of workers, $\mathrm{E}$ ) in the employment equation or the annual wage rate, $\mathrm{W}$, in the wage equation. The dummy variable $\mathrm{D}$ equals 1 if the plant had ownership change in the 1977-87 period. O equals 1 if the plant is initially owned by an acquiring firm in 1977 and operated through 1987. The omitted category is non-acquiring firms' own plants. Our specifications also include interaction terms, $D^{*} \operatorname{lnE}_{77}$ and $\mathrm{OC}_{83-87}{ }^{*} \mathrm{InE}_{77}$, since the data reveal that large firms

14 For example, see Bloch (1979); Ashenfelter and Krueger (1994); and Blackburn and Neumark (1995). 
(or plants) behave differently from small ones.

Empirically, most of the variables included in the right side of Equation (1) have been found important in reduced form regressions of wages and employment change. ${ }^{15}$ The total number of employees measures employment and wages are annual salaries, deflated by the CPI. ${ }^{16}$ We note that this measure of wages does not include non-wage costs associated with labor because separate data on these costs are not available for both production and non-production workers. ${ }^{17}$

We use a variety of control variables; ÄT denotes change in the machinery and equipment to capital stock ratio; $\ddot{A}(K / L)$ is the percentage change in the capital to labor ratio; and $\ddot{A}(N / P)$ denotes the percentage change in the non-production worker $(\mathrm{N})$ to production worker $(\mathrm{P})$ ratio. This variable is used in the wage equation to control for the potential effect of skill mix on wage changes. In the employment equation, we used the variable $\ddot{A}(N W / P W)$ in which NW and PW denote the real wage rates of nonproduction workers and production workers, respectively. While these measures are crude, they are designed to control for changes in technology (we assume that given the same level of capital stock, the plant that uses more equipment and machinery is more technologically advanced) changes in capital intensity, and changes in the skill mix of labor. ${ }^{18}$

Age is a series of dummy variables defined as

Age1 $=1$ if the plant began operation from 1973 to $1977 .{ }^{19}$

Age2 = 1 if the plant bean operation from 1968 to 1972 .

Age3 = 1 if the plant began operation from 1964 to 1967 .

Age4 $=1$ if the plant began operation in 1963 or before.

Multi is a dummy variable that equals 1 if it is a plant owned by a multi-unit firm. Region and IND

15 For example, Brown and Medoff (1989) and Dunne and Roberts (1990) found that employers' size and age had a significant impact on wages. Kruger and Summers (1987) and Dickens and Katz (1987) found that labor productivity (value-added per worker) is important in explaining firm or industry wage variation. Finally, Dunne and Roberts (1990) found that the capital labor ratio, 2-digit industries, and geographic regions are important factors in determining wages.

16 Consumer price index taken from the Survey of Current Business (September, 1993).

17 In addition, Dunne and Roberts (1993) found that "non-wage costs are a poorly reported variable in the census data ... many of the plants have this variable imputed..." (p. 7). Following Dunne and Roberts, we do not include non-wage costs in the measurement of wages.

18 Since the acquisition may be associated with changes in these variables, they should be instrumented. Their exclusion does not alter the basic findings. Examination of the impacts of ownership change on, for example, the skill composition of the firm is an important area for inquiry. It goes well beyond the scope of this study.

19 Plants that began operation after 1977 are excluded from the estimation. 
denote the nine census regions and 4-digit industry dummies. ${ }^{20}$ Finally, $\mathrm{e}_{i}$ is an error term.

Since $E_{77}$ and $W_{77}$ may reflect "transitory" rather than "initial" conditions of plants acquired after 1977 , it would be better to use data on these variables several years before the plant is acquired to describe its initial condition. However, doing so requires continuous data, which in turn reduces our sample size significantly. Since we found that the results based on a proxy -- the average of 1972 and 1977 values were very similar to those based on using 1977 values alone, we relied on the E77 and W77.

We also include plant size variables since our work suggests that acquisitions of large and small plants generally are associated with different motivations. For example, McGuckin and Nguyen (1995) find that large plants typically have poor performance before an ownership change and improve their productivity performance after it. This is consistent with the managerial discipline theory of mergers, which argues that mergers and corporate takeovers are designed to replace or change the policies of bad managers who fail to maximize shareholder value. ${ }^{21}$ In contrast, ownership change at smaller plants appears to be more often motivated by possibilities for synergistic efficiencies because the typical plant performs above average before the change and also improves after it. Although there is substantial noise in the relationship, based on this evidence we anticipate a pattern of employment gains at smaller plants and losses at larger plants involved in ownership changes.

\section{PLANT CLOSING}

The regression analysis outlined above is based on surviving plants: Each equation relates ownership change to changes in wages, and employment estimated using data on surviving plants. Thus, it is important to address the issue of plant closing or exiting after ownership change. To do so, we follow a standard model of plant survival in the literature to specify an empirical model of plant closing. Specifically, plant closing (PC) is specified as a function of plant size, $\ln _{77}$, and plant age, $A_{\mathrm{li}}$ (see e. g., Dunne, Roberts and Samuelson, 1988, Baldwin, 1995, and Roberts, 1996) ${ }^{22}$. In keeping with McGuckin, Nguyen and Reznek (1998), we also include other plant characteristics as control variables: (1) Ownership change (D); (2) plant owned by the acquiring firm before ownership change $(O)^{23}$; (3) initial relative productivity $\left(\mathrm{RLP}_{77}\right)$; (4) industry (IND); (5) Regions. (6) Finally, we allow for non-linear effects of initial productivity and employment size on plant closure. Thus, our empirical model is

20 The nine census regions are New England, Mid Atlantic, South Atlantic, Pacific Mountains, Eastern North Central, Eastern South Central, Western North Central, and Western South Central.

21 See Mork, Shleifer and Vishny, 1988; Matsusaka, 1993; and McGuckin and Nguyen, 1995.

22 For a recent comprehensive survey of research on plant (or firm) entry, exit and survival, see Caves, 1998.

23 The omitted category is plants that were owned by non-acquiring firms in 1977. 


$$
\begin{aligned}
& P C_{87}=a_{0}+a_{1} D+a_{2} O+a_{3} R L P_{77}+a_{4} \ln E_{77}+a_{13} D^{*} R L P_{77} \\
& +a_{14} D^{*} \ln E_{77}+a_{23} O^{*} \ln E_{77}+a_{33}\left(R L P_{77}\right)^{2}+a_{44}\left(\ln E_{77}\right) 2
\end{aligned}
$$

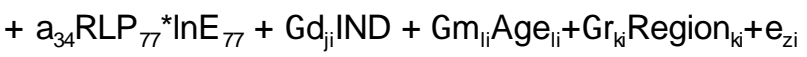

where $\mathrm{PC}_{87}$ equals 1 if the plant was closed by 1987; and the remaining variables are defined as before.

Equation (2) can be estimated using the Ordinary Least Squares (OLS) Method (or linear probability model); however, this method has been shown be inadequate when the dependent variable is discrete. We, therefore, use the Probit regression method to estimate our model because is better suited than OLS when the response is discrete (see Green, 1993). ${ }^{24}$

\section{ENDOGENOUS OWNERSHIP CHANGE}

Estimates of Equation (1) are consistent if $\mathrm{OC}$ is not correlated with the error term of the wage (or employment) equation, $e_{i}$. However, there are good reasons to expect this assumption is invalid.

Recent studies using samples covering a wide range of transaction types suggest that ownership change and plant productivity growth are positively correlated throughout the 1980s merger wave. ${ }^{25}$ This positive relationship forms the basis for our econometric specification of the selection equation that predicts which plants will experience ownership changes. The key point is that this positive relationship is observed whether or not the plant is performing poorly (relative to other plants in its industry) before the ownership change. In fact the vast majority of ownership change transactions involve acquisition (and improvement) of good performers. As we argued above, this difference in pre-ownership change performance is systematic of differing motivations for the ownership change. Poorly performing plants are more likely to involve managerial discipline motives, while synergies are more likely to drive acquisitions of above average performers.

This relationship forms the basis for construction of an instrumental variable to use in estimating equation (1). An instrumental variable for the probability of ownership change is constructed from the reduced form probit regression, Equation (2):

$$
D_{i}=b_{0}+b_{1} R L P_{7 \pi}+b_{2} \ln E_{7 \pi}+b_{3}\left(R L P_{7 \pi}\right)^{2}+b_{4}\left(R L P_{7 \pi}\right)^{3}+b_{5}\left(\ln E_{7 \pi}\right)^{2}+b_{6}\left(\ln E_{7 \pi}\right)^{3}
$$

\footnotetext{
24 We did estimate equation (2) using OLS, but the results (not reported here) do not alter our conclusions based on the Probit regression results.

25 For examples, Lichtenberg and Seigel (1992a) and McGuckin and Nguyen (1995) conclude that ownership changes are positively associated with productivity growth in the U.S. manufacturing sector. In addition, studies by Long and Ravenscraft (1994) and Lichtenberg and Seigel (1992b) of a particular transaction type, leveraged buyouts, find improved productivity following ownership change. Baldwin (1991) obtains a similar result -improvements in productivity following ownership change -- using Canadian establishment data.
} 


$$
+b_{7}\left(R L P_{7 \pi i}^{*} \ln E_{77 i}\right)+G d_{j i} I N D_{j i}+G m_{1 i} A g e_{l i}+G{ }_{k i} R \text { egion }_{k i}+e_{2 i} .
$$

Denoting $\hat{D}$ as the fitted value of $D$, an instrumental variable for the probability of ownership change is constructed as $P(I)=q(-\hat{D})$, where $q$ is the cumulative density function for the standard normal variable.

\section{REGRESSION RESULTS}

\section{The Wage Change Equation}

Table III shows the OLS estimates of the wage growth equations in column (1), with column (2) providing the instrumental variable estimates. In the interest of simplicity we do not report estimates using breakdowns of the ownership change variable within the 1977-87 period. They support the results for the entire period. The coefficients for the control variables are suppressed in some instances and generally are discussed tangentially. ${ }^{26}$ They improve the fit and appear sensible, but as part of a reduced form they have less interest in themselves.

All the coefficients on the ownership change variable (D) are positive and statistically significant at the level of one percent. The coefficients on the interaction between ownership change and size $\left(D^{*} \ln E_{77}\right)$ are significantly negative using OLS indicating that smaller plants, wages increase more quickly for plants undergoing ownership change than for plants not having an ownership change. But for larger plants the relationship is reversed with wages increasing faster for plants not undergoing ownership change. At a plant of average size the relationship is positive with worker wages increasing 4.2 percent faster in plants experiencing ownership change during 1977-87. ${ }^{27}$

It appears that OLS underestimates the effect of ownership change on wage growth. Using the instrumental variable estimates in Column (2) we find an average-sized plant with ownership change increased wages 30.2 percent faster in plants that had ownership change. That is about 3.0 percent a year during the 10-year period 1977-87. At the $90^{\text {th }}$ percentile $\left(\operatorname{lnTE}_{77}=5.3\right)$ the size distribution there is no difference in wage growth between plants undergoing ownership change and those with the same ownership over the period. Beyond that, plants not having ownership change tend to increase their worker wages at a faster rate than plants experiencing ownership change.

We only deal with the other coefficients briefly. The negative coefficients for the age variables imply

26 Complete regression results are available from the authors upon request.

27 The OLS estimates of .144 for $D$ in Column (1) [with the mean of $\ln _{77}$ equal to 3.00] imply that an average sized plant experiencing ownership change increased its worker wages 4.2 percent $[=.144-.034(3.0)]$ faster than that of plants not undergoing ownership change. 
that younger plants increase worker wages faster than older plants. There are various arguments that might be consistent with this finding. For example, if wage changes are positively related to firm (or plant) growth, then this finding is consistent with previous evidence that young firm (or plant) grow faster than older ones (e.g., see Evans, 1987).

The variables representing the initial condition of the plant are also significantly correlated with wage growth. The coefficients for $\operatorname{lnE}_{77}$ (initial size) are significantly positive, implying that larger plants increase their worker's wages faster than smaller plants. In contrast, the coefficients for initial wages are negative and significant, indicating that plants paying high wages at the start of the period tend to increase their worker's wages at a lower rate than those initially paid lower wages. Thus, there is regression to the mean in the data.

\section{THE EMPLOYMENT CHANGE EQUATION}

Table IV reports the coefficients for the employment equations: Columns (1) is based on OLS with Column (2) showing the instrumental variable estimates. As with wages the OLS coefficient for the ownership change variable, $D$, is positive and that for the associated interaction term is negative and significant. The relatively small negative coefficient on the interaction term means that the size effect is not sufficient to make the employment change negative except for the very largest plants. Fixing employment at the sample mean, plants changing ownership increased their labor force faster than plants having no ownership change. And the difference was quite large, more than 19 percent greater. Only when a plant fell in the top 15 percentile of the size distribution did plants without ownership change grow faster.

The results based on the instrumental variable method are more positive with regard to the impact of ownership change. Column (2) shows that both the coefficient for D equals .333 and statistically significant, while that for $D^{*} \mid n E_{77}$ is positive and insignificant. Thus, once the endogenity of ownership change is accounted for, acquired plants increased their employment at a rate of 3.3 percent a year faster than that of non-acquired plants regardless of size.

The coefficient for $O$ is not significantly different from zero. This indicates that increases in employment at purchased plants did not come from workers transferred from the existing plants of the acquiring firms.

The negative coefficients for the age variables suggest that older plants increase their employment at a slower rate than younger plants. This is consistent with the fact that successful (surviving) young plants grow faster than older plants that have already exploited economies of scale and reached efficient size (e.g., see Evans, 1987 and Caves, 1998).

Finally, the coefficient for initial size $\left(\ln E_{77}\right)$ is negative, while that of initial wages (lnWage $\left.{ }_{77}\right)$ is 
positive. These results indicate that plants that were initially large grew more slowly. On the other hand, plants that paid higher initial wages tend to hire more workers at a faster rate than plants that paid lower initial wages.

\section{Plant Closing Equation}

Estimates from the probit regressions explaining plant closing are reported in Table V. Columns (1) and (2) contain the estimated equations in which ownership change is treated as an exogenous variable, while Columns (3) and (4) show the results instrumenting for D. The coefficients for ownership change are negative and significant. This indicates that plants experiencing ownership change are less likely to be closed than plants not changing owners. Note that when instrumenting for the ownership change variable, the magnitude of its coefficient becomes smaller $(-.291)$ than when ownership change is treated as exogenous $(-.546)$. This indicates that models treating ownership change as exogenous tend to over estimate the negative effect of ownership change on the probability of plant closing.

The non-linear models in which $D$ is allowed to interact with size $\left(\operatorname{lnE} E_{77}\right)$ and productivity $\left(R L P_{77}\right)$ indicate that the estimated coefficients are very sensitive to the treatment of the ownership change variable. When ownership change is treated as an exogenous variable (Column 2), its' estimated coefficient is negative with positive interaction terms. In contrast, when ownership change is treated as an endogenous variable, the estimated coefficient for ownership change becomes positive and the coefficients for the associated interaction terms are negative [see Column (4)]. The negative coefficients for $D^{*} \ln E_{77}$ and $D^{*} R P_{77}$ in Column (4) imply that, as their size and productivity increase, acquired plants become less likely to be closed compared to non- acquired plants. These estimates appear more reasonable than those reported in Column (2), indicating that failure to incorporate endogenous ownership change can generate misleading results.

All the coefficients for $\mathrm{O}$ are positive and significant. Thus, the plants of acquiring firms generate higher probabilities of closing. However, the coefficients for $\mathrm{O}^{*} \mathrm{InE}_{77}$ and $\mathrm{O}^{*} \mathrm{RL} \mathrm{P}_{77}$ are significantly negative, suggesting that for large and highly productive plants the probability of closure was lower. ${ }^{28}$

Finally, the results uniformly show that plant characteristics and initial conditions are significantly correlated with plant closing. The negative and significant coefficients for $\ln E_{77}$ and $R L P_{77}$ suggest that larger and more productive plants had significantly lower rates of closing.

The significant and negative coefficients for the age variables indicate that closing rates are higher for younger plants (Age1, the omitted category). This result is consistent with the findings of Dunne and

\footnotetext{
28 The typical acquirers' plant is much larger (254 versus 33 employees) and more productive ( 20 percent above the industry average versus 9 percent below) than the typical non-acquirers' plant.
} 
Roberts (1990) and Dunne, Roberts, and Samuelson (1989).

\section{DISCUSSION}

Our plant level regressions results do not support the claim that the typical acquisition cuts wages or destroys jobs by either reducing employment growth in surviving plants or by increasing the probability of plants closing. Moreover, acquiring firms showed little inclination to reduce employment at plants they operated both before and after acquisitions. Acquiring firms are, however, somewhat more likely to close plants that they owned prior to acquisition.

While we find that, for the typical plant, ownership change is positive for both wages and employment, the impacts are more problematic when viewed from the standpoint of the typical worker. After controlling for individual plant characteristics, wages grew about 30.2 percent faster at an average size plant undergoing ownership change over the period 1977-87. However, for plants at the top $10^{\text {th }}$ percentile of the size distribution, wages grew slower after an ownership change. Since these plants account for a substantial fraction of the work force, the typical worker fares more poorly than the typical plant. Using the estimates for the wage change equation, we find that 82 percent of employees had lower growth rates in wages after acquisition. For our sample, this estimate implies approximately 3 million workers experienced lower wage growth. Thus, there is a case for the proposition that ownership change adversely affects the wages of a substantial fraction of the work force.

On the other hand, the level of wages at acquired plants is higher, even after accounting for size effects. So while acquisitions slow wage growth for workers in large plants, wages remain above average for these workers. Moreover, acquiring firms tend to have slightly higher wages. This result does not support the notion that ownership changes cut wages and is consistent with McGuckin, Nguyen and Reznek's (1998) findings for the U.S . Food manufacturing industry. This finding, however, is inconsistent with Brown and Medoff's (1988) and Lichtenberg and Siegel's (1992) findings that wage changes associated with ownership changes are relatively small. We note, however, that Brown and Medoff's results are based on firm-level data for only one state (Michigan). McGuckin, Nguyen and Reznek (1998) show that firm-level data are too aggregative to capture changes in the composition of the firm.

Lichtenberg and Siegel use plant-level data, but their sample includes only large plants, while our data include the whole universe of U.S. manufacturing. More important, we think that the difference between Lichtenberg and Siegel's results and ours is mainly because they classify plants into two categories: acquired plants and non-acquired plants. This categorization puts acquiring firms' existing plants together with non-acquiring firms' plants in one group and compares them with all acquired plants. 
Because wages of acquiring firms' plants grew faster than those of non-acquiring plants, grouping them together would bias the results. In contrast, we classify our plants into three categories: acquired plants, acquiring firms' existing plants and non-acquiring firms' plants. This grouping of plants help us isolate the effect of ownership changes on wages and employment in each category of plants.

Our finding that ownership changes have a significant and positive effect on employment growth in acquired plants is also consistent with McGuckin, Nguyen and Reznek's finding; but it is not consistent with Brown and Medoff's or Lichtenberg and Siegel's results. Again, we this may be due to our introduction of individual components of firms into the regressions.

The probit models reported in Table $\mathrm{V}$ provide estimates of the probabilities of plant closure for plants that experienced ownership change, plants originally owned by acquirers, and plants owned by nonacquirers in 1977. Table VI shows the results of this exercise for 3 plant sizes. Except for model 4, the probability of closing is substantially smaller for acquired plants regardless of size. In model 4 the probability is higher for some plants. But, even in model 4 the probability that a plant of average size will be closed is only $1 / 3$, more than 10 percentage points lower than a non-acquirer. At a size of 49 employees, about half the average, both acquired plants and non-acquirers' plants had the same probability of closing. Below that the probability of closing for acquired plants is larger than for non-acquirers' plants. For example, the probability is about six percentage points higher for acquired plants of 33 employees. While this size plant is very small relative to the typical acquired plant, it is about average for a non-acquiring firm. In all models, the estimated probabilities of closing for are highest for the plant's owned by acquiring firms. However, as the size gets larger, the difference in these probabilities becomes smaller.

These results strongly suggest that plants with new owners had a much greater chance to survive. And plants of firms undertaking acquisitions, particularly small ones, were more likely to be closed than those owned by non- acquirers.

It is useful to put these findings in a somewhat broader perspective, the productivity performance of the plant and the incentives and motivations for merger. McGuckin and Nguyen (1995) found that the vast bulk of ownership change activity is associated with synergistic efficiencies. For a much smaller fraction of the acquisitions, mostly involving larger plants, the motive for the acquisition was disciplining inefficient managers. Both types of ownership change improved productivity. But, as reflected in the frequently expressed hostility toward mergers by labor unions and the press, the costs are likely to be high to many workers. This is certainly reflected in the data developed here where the impacts of ownership change are much less positive for the typical worker than for the typical plant.

Yet it is the larger (poorly performing) plants where the managerial discipline hypothesis is most valid and where reductions in the growth rates of employment and wages are likely to be most beneficial. Thus, the overall benefits of ownership changes -- better productivity and movements of resources from 
lower to higher valued uses -- are likely to be large. While there are losses for many workers, the net effect is slightly positive. Moreover, in undertaking a true cost-benefit calculation, the loss of jobs would need to be offset to the extent workers laid off due to merger were hired elsewhere.

\section{CONCLUDING REMARKS}

In this study, we examined the effects of ownership changes on employment, wages and plant closing for the entire U.S. manufacturing sector for the period 1977-87. We found that ownership changes were associated with increases in wages at the typical plant. However, the typical worker fared more poorly because the negative impacts on wages were highest at larger plants where the benefits of restructuring were greatest.

Thus, we found a mixed picture for workers, with the bottom line heavily dependent on the size of the plant experiencing ownership change. Even though acquisition reduced wage growth at larger plants, it is the larger (poorly performing) plants where reductions in the growth rates of wages are likely to be most beneficial. In short, mergers and acquisitions play an important role in the dynamic efficiency of the economy. While the impacts on workers can be high, it is unlikely that restrictions on such transactions would be beneficial in situations beyond prevention of the creation of monopoly power. Even then, the efficiency enhancing effects of the acquisition need to be carefully weighed.

Finally, we found that the probability of closing is substantially smaller for acquired plants. We also find that the estimated probabilities of closing are highest for acquiring firms' existing plants . However, as the size gets larger, the difference in these probabilities becomes smaller. These results strongly suggest that plants with new owners had a much greater chance to survive. And plants of firms undertaking acquisitions, particularly small ones, were more likely to be closed than those owned by non-acquirers. 


\section{REFERENCES}

Ashenfelter, O. and Krueger, A.B. (1994), "Estimates of the Economic Returns on Schooling from a New Sample of Twins," American Economic Review, Vol. 84, Number 5 (December), pp. 1157-73.

Audretsch, D. B. (1995) “Innovation, Growth, and Survival," International Journal of Industrial Organization, 13:4, pp. 441-457.

Baldwin, J. (1991), "The Dynamics of the Competitive Process," mimeo, Queen's University.

Bloch, Farrell E. (1979), Evaluating Manpower Training Programs, Greenwich, CT: JAI Press.

Brown, C. and Medoff, J.L. (1988), "The Impact of Firm Acquisition on Labor," in Corporate Takeovers:

Causes and Consequences, Alan J. Auerbach (ed.), Chicago and London: The University of Chicago Press, pp. 9-25.

(1989), "The Employer Size-Wage Effect," Journal of Political Economy,

97(November), pp. 1027-1059.

(1990), Employers Large and Small. Cambridge, MA: The Harvard University Press.

Caves, R. E. (1998), "Industrial Organization and New Findings on the Turnover and Mobility of Firms," Journal of Economic Literature, Vol. XXXVI (December), pp. 1947-1982.

(1989), "Mergers, Takeovers, and Economic Efficiency: Foresight vs. Hindsight," International journal of Industrial Organization, 7 (1), pp. 151-174.

Dickens, W.T. and Katz, L.F. (1987), "Inter-Industry Wage Differences and Industry Characteristics," in Unemployment and the Structure of Labor Markets, Kevin Lang and Jonathan Leonard (eds.), New York: Basil Blackwell.

Dunne, T. and Roberts, M. (1993), "The Long-Run Demand for Labor: Estimates from Census Establishment Data," CES Discussion Paper 93-13, U.S. Bureau of the Census, Center for Economic Studies, Washington, D.C. (1990), "Wages and the Risk of Plant Closings," CES Discussion Paper 90-6, U.S. Bureau of the Census, Center for Economic Studies, Washington, D.C.

Dunne, T., Roberts, M., and Samuelson, L.(1988), "Patterns of Firm Entry and Exit in U.S. Manufacturing Industries," RAND Journal of Economics, Vol. 19, No. 4 (Winter), pp. 495-515.

(1989), "The Growth and Failure of U.S. Manufacturing Plants,"

Quarterly Journal of Economics, Volume 104, Number 4, (November), pp. 671-98.

Gauchely, J., Groshen, E., and Neumark, D. (1994), "Do Hostile Takeovers Reduce Extramarginal Wage Payments?," mimeo.

Eckbo, B. E. (1983), "Horizontal Mergers, Collusion, and Stockholder Wealth," Journal of Financial 
Economics, 11 (April), pp. 241-273.

Evans, D. S. (1987),"The Relationship Between Firm Growth, Size, and Age: Estimates for 100 Manufacturing Industries," Journal Of Industrial Economics, Vol. XXXV, No. 4 (June), pp. 567-581.

Guerin-Calvert, M., McGuckin, R.H., and Warren-Boulton, F.R. (1987), "State and Federal Regulation in the Market for Corporate Control", Antitrust Bulletin, Number 32, pp. 661-691.

Jensen, M. C. (1988), "Takeovers: Their Causes and Consequences," Journal of Economic Perspectives, vol. 2, pp. 21-48.

Jensen, J. B., McGuckin, R.H., and Stiroh, K.J. (1998), "The Impact of Vintage and Survival on Productivity: Evidence from Cohorts of U.S. Manufacturing Plants," working paper.

Green, W. H. (1993), Econometric Analysis, second edition, New York: MacMillan Publishing Company. Grundfest, J. A., Jarrell, G., Salop, S. C., and White, L. J. (1988), "Panel Discussion: Corporate Takeovers and Public Policies," in Alan J. Auerbach (ed.), Corporate Takeovers: Causes and Consequences, Chicago and London: The University of Chicago Press.

Krueger, A.B. and Summers, L.H. (1987), "Reflections on the Inter-Industry Wage Structure," in Unemployment and the Structure of Labor Markets, Kevin Lang and Jonathan S. Leonard (eds.), New York: Basil Blackwell, pp. 17-47.

Lichtenberg, F.R. and Siegel, D. (1992a), "Productivity and Changes in Ownership of Manufacturing Plants," in Corporate Takeovers and Productivity, F. Lichtenberg (ed.), Cambridge: The MIT Press, pp. 2543.

(1992b), "Takeovers and Corporate Overhead," in Corporate Takeovers and Productivity, F. Lichtenberg (ed.), Cambridge: The MIT Press, pp. 45-67.

Long, W.F. and Ravenscraft, D.J. (1992), "The Financial Performance of Whole Company LBOs," CES Discussion Paper, 93-16, U.S. Bureau of the Census, Center for Economic Studies, Washington, D.C.

McGuckin, R.H. and Nguyen, S.V. (1995), "On Productivity and Plant Ownership Change: New Evidence from the LRD," The RAND Journal of Economics, Volume 26, Number 2, pp. 257-76.

McGuckin, R.H., Nguyen, S.V., and Reznek, A.P. (1998), " On the Impact of Ownership Change on Labor: Evidence From Food Manufacturing Plant Level Data, in Labor Statistics Measurement, J. Haltiwanger, M. Manser, and R. Toppel (eds.), National Bureau of Economic Research, Studies in Income and Wealth, Vol. 60, Chicago and London: The University of Chicago Press, pp. 207-246,

McGuckin, R.H. and Pascoe, G. (1988), "The Longitudinal Research Database: Status and Research Possibilities," Survey of Current Business, Volume 68, Number 11, pp. 30-37.

McGuckin, R.H. and Stiroh, K.J. (1999), "Understanding Productivity Growth: Entry, Survival, and the Competitive Process," Economic Research Report \#1236-99-RR, The Conference Board, New York, 
NY.

Mellow, W. (1982), "Employer Size and Wages," Review of Economics and Statistics, 64 (August), pp. 495501.

Nguyen, S.V. (1998) THE Manufacturing Plant Ownership Change Database: Its Construction and Usefulness, Journal of Economic and Social Measurement, No. 24, pp. 209-232.

Oi, W. Y. (1983), "The Fixed Employment Costs and Specialized Labor," in The Measurement of Labor Costs, Jack E. Triplett (ed.). Chicago: The University of Chicago Press.

Posner, R. (1976), Antitrust Law: An Economic Perspective, Chicago: The University of Chicago Press. Rule, C.F. and Meyer, D.L. (1994), "Toward a Merger Policy that Maximizes Welfare: Enforcement by Careful Analysis Not Numbers", in The Antitrust Impulse, Volume 1, Theodore Kovaleff (ed.), Armonk, New York: M. Sharpe. 
TABLE I

EMPLOYMENT AND WAGES AT PLANTS IN OPERATION, 1977-87, BY OWNERSHIP STATUS

\begin{tabular}{|c|c|c|c|c|c|c|c|}
\hline \multirow[t]{2}{*}{$\begin{array}{l}\text { Plant Type/Ownership Status } \\
\text { (1987) }\end{array}$} & \multicolumn{2}{|c|}{ Total Employment } & \multicolumn{2}{|c|}{$\begin{array}{c}\text { Average } \\
\text { Employment }\end{array}$} & \multicolumn{2}{|c|}{ Average Wages } & \multirow[t]{2}{*}{$\begin{array}{l}\text { Number of } \\
\text { Plants }\end{array}$} \\
\hline & 1977 & 1987 & 1977 & 1987 & 1977 & 1987 & \\
\hline Plants Acquired and Kept 1982 & $2,196,756$ & $1,978,755$ & 250 & 225 & 22,319 & 23,069 & 8,784 \\
\hline Plants Acquired and Resold and Kept* & 513,052 & 429,313 & 239 & 200 & 21,979 & 23,245 & 2,146 \\
\hline TOTAL & $3,723,784$ & $3,389,622$ & 232 & 211 & 21,998 & 22,856 & 16,061 \\
\hline \multicolumn{8}{|l|}{$\begin{array}{r}\text { Continuing Plants/Same Ownership } \\
\text { By Firms with Acquisitions }\end{array}$} \\
\hline TOTAL & $5,157,603$ & $4,903,042$ & 413 & 393 & 23,117 & 24,599 & 12,487 \\
\hline Non-Acquiring Firms & $4,401,549$ & $4,944,824$ & 37 & 42 & 20,793 & 19,571 & 118,174 \\
\hline TOTAL & $9,559,152$ & $9,847,866$ & 73 & 75 & 21,015 & 20,359 & 130,661 \\
\hline $\begin{array}{r}\text { Exiting Plants } \\
\text { Owned by Firms with Acquisitions }\end{array}$ & $1,623,025$ & ----- & 169 & ----- & ----- & ----- & 9,582 \\
\hline $\begin{array}{r}\text { Purchased by Firms with } \\
\text { Acquisitions }\end{array}$ & 681,322 & ---- & 161 & ---- & 21,210 & $-\cdots--$ & 4,222 \\
\hline Owned by Non-Acquiring Firms & $2,883,112$ & & 19 & -- & 18,878 & ---- & 154,359 \\
\hline TOTAL & $5,187,459$ & ----- & 31 & ---- & 19,059 & ---- & 168,163 \\
\hline $\begin{array}{r}\text { New Plants } \\
\text { By Firms with Acquisition }\end{array}$ & ----- & $1,517,278$ & ----- & 118 & ----- & 22,351 & 12,912 \\
\hline Non-Acquiring Firm & ----- & $2,959,646$ & ----- & 16 & ---- & 17,061 & 181,685 \\
\hline TOTAL & ----- & $4,476,924$ & ---- & 23 & ---- & 17,412 & 190,865 \\
\hline TOTAL & $18,470,395$ & $17,714,800$ & 59 & 52 & 20,049 & 18,652 & 314,885 \\
\hline
\end{tabular}

Because 1987 is the ending date, almost all of these observed resales are from acquisitions in the 1977-82 period. 
TABLE II

EMPLOYMENT AND WAGES AT PLANTS IN OPERATION IN BOTH 1977 AND 1987

BY OWNERSHIP STATUS (1987) AND SIZE CLASS (1977)

(All Manufacturing)

\begin{tabular}{|c|c|c|c|c|c|c|c|}
\hline \multirow[t]{2}{*}{ Plant Ownership Status } & \multirow[t]{2}{*}{$\begin{array}{l}\text { Number } \\
\text { of Plants }\end{array}$} & \multicolumn{3}{|c|}{$\begin{array}{l}\text { Average Employment } \\
\text { (Number of Employees) }\end{array}$} & \multicolumn{3}{|c|}{ Average Annual Wages $(\$ 1,000 \mathrm{~s})$} \\
\hline & & 1977 & 1987 & $\begin{array}{c}\text { Ratio } \\
(1987 / \\
1977)\end{array}$ & 1977 & 1987 & $\begin{array}{r}\text { Ratio } \\
(1987 / \\
1977) \\
\end{array}$ \\
\hline $\begin{array}{l}\text { Non-Acquiring Firm } \\
\text { Plant Size Class }\end{array}$ & & & & & & & \\
\hline $\begin{array}{r}1-50 \\
51-100 \\
101-250 \\
251-500 \\
>500\end{array}$ & $\begin{array}{c}98,778 \\
10,645 \\
6,319 \\
1,692 \\
721\end{array}$ & $\begin{array}{c}13.6 \\
70.0 \\
150.7 \\
338.1 \\
1092.0\end{array}$ & $\begin{array}{c}20.0 \\
78.1 \\
150.8 \\
315.0 \\
906.1\end{array}$ & $\begin{array}{c}1.47 \\
1.12 \\
1.00 \\
.93 \\
.83\end{array}$ & $\begin{array}{l}21.0 \\
20.0 \\
19.6 \\
19.2 \\
22.5\end{array}$ & $\begin{array}{l}19.3 \\
21.0 \\
20.9 \\
20.5 \\
24.5\end{array}$ & $\begin{array}{c}.92 \\
1.05 \\
1.07 \\
1.07 \\
1.09\end{array}$ \\
\hline SUBTOTAL & 118,155 & 37.3 & 41.9 & 1.12 & 20.8 & 19.6 & .94 \\
\hline $\begin{array}{l}\text { Acquiring Firm } \\
\text { Plant Size Class }\end{array}$ & & & & & & & \\
\hline $\begin{array}{r}1-50 \\
51-100 \\
101-250 \\
251-500 \\
>500\end{array}$ & $\begin{array}{l}7,468 \\
4,984 \\
7,731 \\
4,471 \\
3,891\end{array}$ & $\begin{array}{c}25.4 \\
74.0 \\
163.0 \\
351.7 \\
1411.0\end{array}$ & $\begin{array}{c}46.1 \\
94.6 \\
174.3 \\
338.1 \\
1186.8\end{array}$ & $\begin{array}{l}1.8 \\
1.3 \\
1.1 \\
.96 \\
.84\end{array}$ & $\begin{array}{l}22.6 \\
21.8 \\
21.8 \\
21.8 \\
25.4\end{array}$ & $\begin{array}{l}22.7 \\
22.7 \\
23.1 \\
23.5 \\
27.8\end{array}$ & $\begin{array}{l}1.00 \\
1.04 \\
1.06 \\
1.08 \\
1.00\end{array}$ \\
\hline SUBTOTAL & 28,545 & 311.0 & 290.5 & .93 & 22.5 & 23.6 & 1.05 \\
\hline TOTAL & 146,700 & 90.5 & 90.2 & 1.00 & 21.1 & 20.4 & .97 \\
\hline
\end{tabular}


TABLE III

THE WAGE EQUATION

(t-ratios in parentheses)

Dependent Variable: $\ln \left(W_{87}\right)-\ln \left(W_{77}\right)$

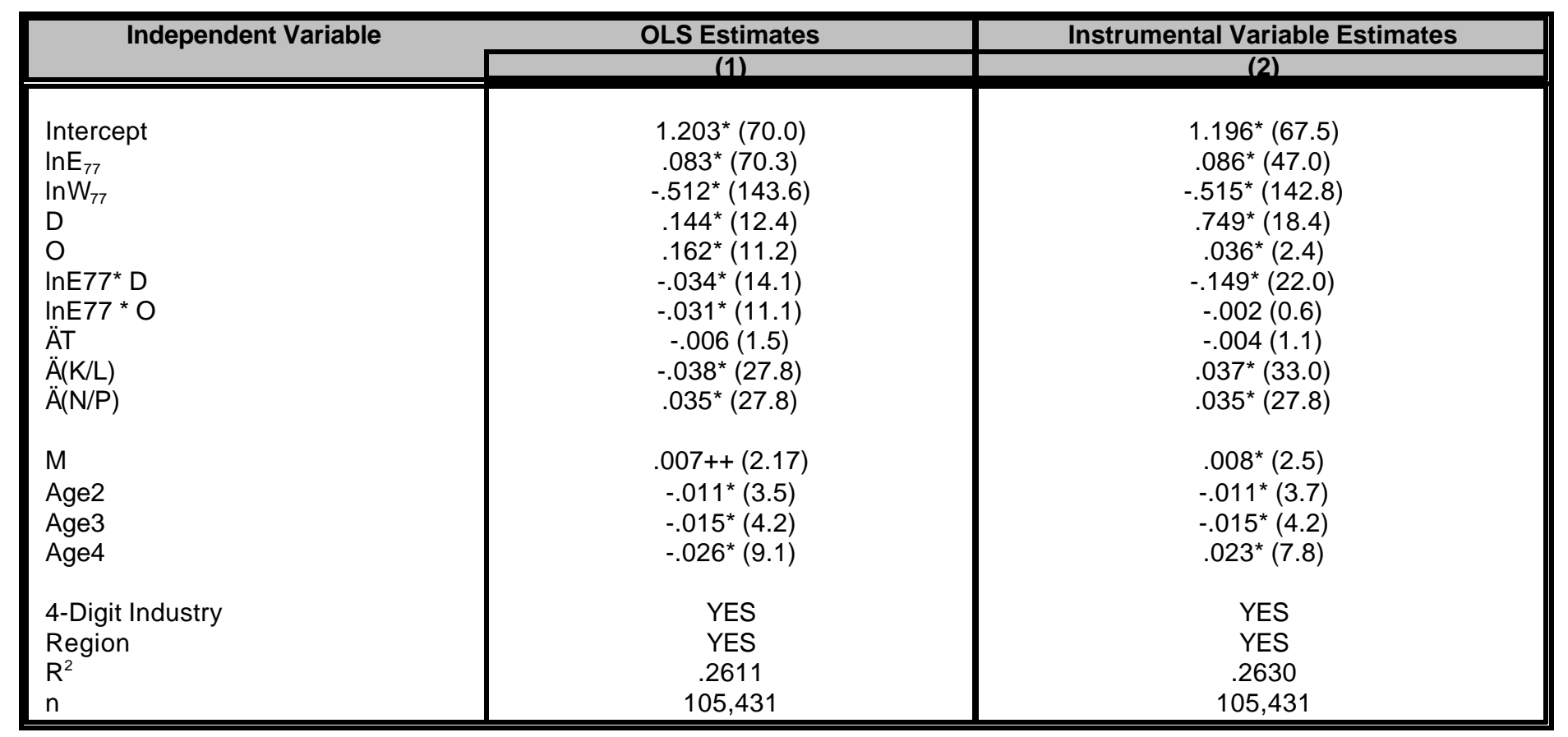

* denotes "significant" at the one percent level.

++ denotes "significant" at the five percent level.

+ denotes "significant" at the ten percent level. 
TABLE IV

THE EMPLOYMENT EQUATION

(t-ratios in parentheses)

Dependent Variable: $\ln \left(E_{87}\right)-\ln \left(E_{77}\right)$

\begin{tabular}{|c|c|c|}
\hline \multirow[t]{2}{*}{ Independent Variable } & OLS Estimates & Instrumental Variable Estimates \\
\hline & $(1)$ & $(2)$ \\
\hline Intercept & $-.328 *(9.2)$ & $-.189^{*}(5.1)$ \\
\hline $\ln E_{77}$ & $-.146^{*}(59.6)$ & $-.188^{*}(49.3)$ \\
\hline $\ln \mathrm{W}_{77}$ & $.348^{*}(46.8)$ & $.333^{*}(44.0)$ \\
\hline D & $.424^{*}(17.6)$ & $.382^{*}(4.5)$ \\
\hline $\mathrm{O}$ & $.034(1.1)$ & $-.059+(1.9)$ \\
\hline $\ln E 77^{*} \mathrm{D}$ & $-.077^{*}(15.3)$ & $.009(0.6)$ \\
\hline $\ln E 77$ * $\mathrm{O}$ & $.009(1.5)$ & $.023^{*}(3.8)$ \\
\hline & $-.026^{*}(3.4)$ & $-.028(3.7)$ \\
\hline$\ddot{A}(K / L)$ & $-.094^{*}(39.6)$ & $-.092(39.0)$ \\
\hline Ä(NW/PW) & $.075^{*}(21.7)$ & $.075(21.6)$ \\
\hline & & - \\
\hline M & $-.012+(1.8)$ & $.004(0.6)$ \\
\hline Age2 & $-.172^{*}(26.9)$ & $-.167(25.9)$ \\
\hline Age3 & $-.237^{*}(31.7)$ & $-.229(30.4)$ \\
\hline Age4 & $-.309^{*}(52.1)$ & $-.297(48.9)$ \\
\hline 4-Digit Industry & YES & YES \\
\hline Region & YES & YES \\
\hline $\mathrm{R}^{2}$ & .1935 & 1919 \\
\hline $\mathrm{n}$ & 105,431 & 105,431 \\
\hline
\end{tabular}

* denotes "significant" at the one percent level.

++ denotes "significant" at the five percent level.

+ denotes "significant" at the ten percent level. 
TABLE V

PROBIT REGRESSION OF PLANT CLOSURE

(standard errors in parentheses)

Dependent Variable: Plant Closure

\begin{tabular}{|c|c|c|c|c|}
\hline & \multicolumn{2}{|c|}{ Simple Probit Regression } & \multicolumn{2}{|c|}{ Instrumenting for $\mathrm{OC}_{77-87}$} \\
\hline & (1) & (2) & (3) & $(4)$ \\
\hline $\begin{array}{l}\text { Intercept } \\
\mathrm{RLP}_{77} \\
\operatorname{lnE}_{77} \\
\left(\mathrm{RLP}_{77}\right)^{2} \\
\left(\operatorname{lnE}_{77}\right)^{2} \\
\operatorname{RLP}_{77}{ }^{2} \ln E_{77} \\
\text { D } \\
\text { O }\end{array}$ & $\begin{array}{c}1.024^{*}(.024) \\
-.0003(.0002) \\
-.271^{*}(.002) \\
---- \\
---- \\
---- \\
-.546^{*}(.011) \\
.102^{*}(.012)\end{array}$ & $\begin{array}{l}1.161^{*}(.026) \\
-.065^{*}(.007) \\
-.342^{*}(.005) \\
.0013^{*}(.0001) \\
.015^{*}(.0009) \\
-.009^{*}(.002) \\
-.827^{*}(.042) \\
.511^{*}(.042)\end{array}$ & $\begin{array}{c}1.032^{*}(.025) \\
-.0004+(.0002) \\
-.275^{\star}(.003) \\
---- \\
---- \\
---- \\
-.291^{*}(.046) \\
.277^{\star}(.012)\end{array}$ & $\begin{array}{c}1.207^{*}(.026) \\
-.088^{*}(.007) \\
-.385^{*}(.006) \\
.0015^{*}(.00009) \\
.024^{*}(.001) \\
-.006^{*}(.002) \\
1.581^{*}(.183) \\
.465^{*}(.041)\end{array}$ \\
\hline $\begin{array}{l}D *{ }^{*} \mathrm{RLP}_{77} \\
\mathrm{D} \text { * } \ln \mathrm{E}_{77} \\
\mathrm{O} * \mathrm{RLP}_{77} \\
\mathrm{O}^{*} \ln \mathrm{In} 77\end{array}$ & $\begin{array}{l}----- \\
----- \\
---- \\
----\end{array}$ & $\begin{array}{c}.019(.012) \\
.056^{\star}(.009) \\
-.048^{*}(.009) \\
-.079^{*}(.008)\end{array}$ & $\begin{array}{l}----- \\
----- \\
---- \\
----\end{array}$ & $\begin{array}{l}-.011^{*}(.025) \\
-.400^{*}(.032) \\
-.043^{*}(.009) \\
-.029^{*}(.008)\end{array}$ \\
\hline $\begin{array}{l}\text { Multi } \\
\text { Age2 } \\
\text { Age3 } \\
\text { Age4 }\end{array}$ & $\begin{array}{l}.359^{*}(.008) \\
-.154^{*}(.007) \\
-.214^{*}(.008) \\
-.147^{*}(.006)\end{array}$ & $\begin{array}{l}.352^{\star}(.008) \\
-.147^{\star}(.007) \\
-.210^{\star}(.008) \\
-.155^{\star}(.006)\end{array}$ & $\begin{array}{l}.268^{*}(.008) \\
-.155^{*}(.007) \\
-.216^{*}(.008) \\
-.151^{*}(.006)\end{array}$ & $\begin{array}{l}.263^{*}(.008) \\
-.149^{*}(.007) \\
-.231^{*}(.008) \\
-.155(.000)\end{array}$ \\
\hline $\begin{array}{l}\text { Region } \\
\text { 4-Digit Industry } \\
n\end{array}$ & $\begin{array}{c}\text { YES } \\
\text { YES } \\
311,783\end{array}$ & $\begin{array}{c}\text { YES } \\
\text { YES } \\
311,783\end{array}$ & $\begin{array}{c}\text { YES } \\
\text { YES } \\
311,783\end{array}$ & $\begin{array}{c}\text { YES } \\
\text { YES } \\
311,783\end{array}$ \\
\hline
\end{tabular}

a $\quad$ closure $=1$ if the plant is closed by 1987; else closure $=0$.

* denotes "significant" at the one percent level.

$+\quad$ denotes "significant" at the five percent level. 
TABLE VI

PROBABILITIES OF PLANT CLOSINGS

\begin{tabular}{|c|c|c|c|c|}
\hline Types of Plants & $\begin{array}{c}\text { Model I } \\
\text { (1) }\end{array}$ & $\begin{array}{l}\text { Model II } \\
\text { (2) }\end{array}$ & $\begin{array}{l}\text { Model III } \\
\text { (3) }\end{array}$ & $\begin{array}{c}\text { Model IV } \\
\text { (4) }\end{array}$ \\
\hline $\begin{array}{l}\text { Acquired Plants } \\
\text { Case 1a } \\
\text { Case 2b } \\
\text { Case 3c }\end{array}$ & $\begin{array}{l}.2218 \\
.2792 \\
.3189\end{array}$ & $\begin{array}{l}.3009 \\
.3676 \\
.4122\end{array}$ & $\begin{array}{l}.2247 \\
.2598 \\
.2856\end{array}$ & $\begin{array}{l}.3279 \\
.4786 \\
.5814\end{array}$ \\
\hline $\begin{array}{l}\text { Acquirers' Own } \\
\text { Plants } \\
\text { Case } 1 \\
\text { Case } 2 \\
\text { Case } 3\end{array}$ & $\begin{array}{l}.4530 \\
.5250 \\
.5703 \\
\end{array}$ & $\begin{array}{l}.5185 \\
.5909 \\
.6354 \\
\end{array}$ & $\begin{array}{l}.4558 \\
.5364 \\
.5895 \\
\end{array}$ & $\begin{array}{l}.5424 \\
.5990 \\
.6380 \\
\end{array}$ \\
\hline $\begin{array}{l}\text { Non-Acquirers' } \\
\text { Plants } \\
\text { Case 1 } \\
\text { Case 2 } \\
\text { Case 3 }\end{array}$ & $\begin{array}{l}.4229 \\
.4843 \\
.5300 \\
\end{array}$ & $\begin{array}{l}.4088 \\
.4812 \\
.5275 \\
\end{array}$ & $\begin{array}{l}.4179 \\
.4770 \\
.5175 \\
\end{array}$ & $\begin{array}{l}.4291 \\
.4786 \\
.5146 \\
\end{array}$ \\
\hline
\end{tabular}

a Case 1: The probabilities are estimated by setting InE77 $=4.60 . \quad(E 77=99)$

b Case 2: The probabilities are estimated by setting $\ln E 77=3.90 . \quad(E 77=49)$

c Case 3: The probabilities are estimated by setting InE77 $=3.50 . \quad(E 77=33)$

The simple means of InE77 for acquired plants, acquirers' plants, and non-acquirers' plants are 4.60, 4.56, and 2.13, respectively. 